\title{
Roma song lyrics: a mirror of social phenomena and values of the Roma ethnic group
}

Streszczenie: Niniejsze opracowanie jest poświęcone muzyce romskiej, wyjątkowemu skarbowi kultury romskiej. Muzyka, która znajduje się w centrum kilku dyscyplin ściśle związanych z pedagogiką społeczną, jest jedynym pozytywnym stereotypem kulturowym i możliwym pomostem między mniejszością romską a społeczeństwem większościowym. Przedmiotem pracy są teksty pieśni cygańskich służące jako środek autoekspresji grupy etnicznej, odzwierciedlający doświadczenia życiowe i warunki życia oraz stanowiący wzmacniający atrybut kultury romskiej. Treści pieśni romskich, jako źródło głębokiego i autentycznego świadectwa samych Romów, zostały poddane analizie mającej na celu znalezienie najbardziej znaczących problemów społeczno-pedagogicznych.

Słowa kluczowe: pieśni romskie, mniejszość etniczna, muzyka cygańska, tożsamość kulturowa, edukacja międzykulturowa

\section{Introduction}

The Roma theme is currently a very hot topic in the field of social sciences and humanities. Particular issues related to the education of Roma children and their subsequent integration and empowerment in the society are crucial and so the research focusing on understanding aspects of culture determining the personality of the Roma pupil has an important place. The research in this area brings valuable findings, but even the less common topics such the phenomenon of Roma music can be clearly grasped in the context of social pedagogy and it may provide insight into the poorly explored field of the culture of Roma people. Consequently, the findings can be interpreted in terms of their possible use by teachers, educators, social workers and others.

Evidently, Roma music lying in the centre of several disciplines closely related to social pedagogy is in the eyes of the Czech majority the only positive cultural stereotype and a possible link between the Roma minority and the majority society. The Roma musical expression is excellent and original 
and can be certainly classified among the most important benefits of the culture of the Roma ethnic group. Simultaneously, Roma music refers to the roots and origins of the entire ethnic groups and has become a mainstay of traditional Roma identity.

One of the leading world researchers in this area is Bálint Sárosi, who presented a comprehensive study of Hungarian traditional Roma music - Gypsy music (1978). Another famous author dealing with the Roma music is Speranta Rădulescu, Romanian ethnomusicologist. The area of her research is very comprehensive. The most interesting is publication Chats about Gypsy music (Rădulescu, 2004), whose core consists of the transcribed interviews with the Roma professional musicians or people who are engaged in the field of the Romani music. The main topic of the dialogues are gypsy issues, culture and the life of Roma ethnic groups. Further, David Malvinni (The Gypsy Caravan: From Real Roma to Imaginary Gypsies in Western Music and film, 2004) and Carol Silverman with her book Romani Routes: Cultural Politics and Balkan Music in Diaspora (Silverman, 2012) cannot miss in the list of authors dedicated to the central theme of this paper. And finally, relatively new publication Gypsy Music in European Culture: from the late eighteenth to the early twentieth centuries (2013) by Anna G. Piotrowska, the Polish musicologist, must be also highlighted.

Similarly, we can find a number of authors fixing on the issue of Roma music in the Czech environment. Especially, monographs by Ševčíková - Sociokulturní a hudebně výchovná specifika romské minority v kontextu doby (2003) and Slyšet, cítit a dotýkat se... (2008) are dominating in the Czech field of the literature dealing with this topic. Ševčíková is a current pedagogue focusing on the music from the perspective of music education and etnopedagogy. Her publications are dedicated to the musical culture of the Roma from the viewpoint of musical-pedagogy and musicology. This author presents a brief overview of the history as well as a look on the current transformation of the Roma music scene in the Czech Republic. In the second part, she pays attention to selected aspects of musicality of the Roma children in the younger and older school age. Her efforts directed to alternative education of the Roma ethnic group through the music based on the application of the empirical and experimental research have an abundant importance for special education.

Zuzana Jurková, the lecturer of ethnomusicology, is another significant author centring on the area of the Roma music. For social pedagogy (especially for multicultural education), the project: Cesty romské hudby (Slovo 
21, @2018) - a document distributed to basic schools, which Jurková wrote an accompanying commentary - is of great importance.

Other important publications partly engaged in the Roma music, musicians and the songs themselves, as well as their characteristic aspects is: Šaj pes dovakeras: Můžeme se domluvit (Hübschmannová, 2002). The author was one of the most important founders of the Romani studies in the Czech Republic, she also laid the foundations of the literary Romani language and was a collector of Roma folklore - fairy tales, stories, proverbs and songs.

Furthermore, texts and sound recordings of the oldest musical folklore of the Vlach Roma from the Czech Republic and Slovakia collected in Vlachicka djila (Davidová, Jurková, 2001) have an enormous value, as well as a publication Čhajori Romani (Davidová, 1999) bringing a unique set of the Roma song poetry. Jana Belišová is a well-known collector of the songs in the Roma settlements in Slovakia. Her major publications are unique collections of songs: Neve gila (Belišová, 2010), Phurikane gila (Belišová, 2002) and Hoj na nej na, Phurikane gila (2) (Belišová, 2006).

Despite the fact that Roma songs are a unique phenomenon reflecting aspects of experience and the way of life of individuals or the entire group, the analysis of the Romani authentic texts is not very common in the Czech research environment. Nevertheless, we can find some very interesting research topics revealing aspects of the ethnic culture of the Roma, self-image, identity and values by analysing the testimonies of the Roma in various literary and art genres. The research: Self Concept of the Romany in the Romany Folk Literature (Ševčíková, 2011) focusing on the understanding of selfconcept of the Romani people through their values and through the reflection of construction of meaningfulness of existential themes in the Romani fairy tales is very important in this area. Another author, Alena Scheinostová (2011) in her research work concentrated on the analysis of the Roma prose to portray the Roma identity attributes of the main characters. In particular, she focused on the thematic analysis of the texts, their compositional and linguistic style, as well as their function in present-day life. This research has shown that the most common themes in the analysed texts have to do with human emotions, experiences and life events.

However, it is evident that all previous researches concentrated mainly on the characters of stories, fairy-tales or song lyrics and described the process of constructing either the identity or the self-image. Furthermore, if the texts were subjected to thematic content analysis, not in such details as it was in our case. Additionally, the researchers explained the personality specifics of 
the Roma themselves as well as the differences between the Roma culture and the culture of the majority on this basis. Lastly, the interpretations of the results of studies directed more to the disciplines of philosophy and culture or sociology (Ševčíková, 2011), special pedagogy (Ševčíková, 2008) or even ethnomusicology (Sározi, 1978; Rădulescu, 2003).

In contrast, the presented study concentrates on living conditions, social problems, events, values and phenomena that can be found in the lyrics as a common part of everyday life of the members of this ethnic group. When research focuses on the characters, it rather seeks roles in the community, experience of everyday life, various worries or difficult situations. So our study conceptually complements existing research on the Czech field.

The general purpose of this investigation was to look at the authentic texts from the perspective of social pedagogy and to interpret the results in the light of the use of music in the multicultural education at schools or to provide new insight to social workers about the Roma minority. Consequently, the main aim of this research was to recognize the reality of life of the Roma from the statements which are designed and presented in the form of Roma song lyrics. Secondly, a partial aim was to analyse and describe living circumstances and the most serious social problems faced by this minority, issues that intimately affect their personal lives and have a strong influence on their life satisfaction, well-being and prosperity.

Furthermore, the benefits of our study can be seen directly in the choice of the research sample. Roma songs, as well as other artefacts of Roma culture, were passed from generation to generation in oral form. Despite this fact, there are several collections of Roma songs in the written form (as mentioned above). The most extensive ethnographic materials in this area are sets of Slovak ethnomusicologist Jana Belišová. The songs were collected directly in Roma settlements, which made the material highly authentic. They were sung directly by Roma people, audio recorded and then published in collections with a transcription of the main melody to the musical notation. Lyrics were presented in the Romani language and translated into the Slovak and English language.

\section{Methods}

For the analysis of linguistic documents, the method of content analysis is widely used, as a highly structured method and selective process of description, representing a significant reduction of information and moreover, it is a rela- 
tively economical method. For our purpose, we combined both approaches to perceiving reality - quantitative and qualitative. Analysis of themes (also thematic / formal / frequency analysis) is the oldest method of content analysis and it is a tool allowing the transfer of verbal communication into measurable variables, belonging to the positivist model and empirical research. The main advantage of this method is in the possibility of the classification into a relatively small number of categories, which must be defined before the beginning of the research. The quantitative approach to research, pivotal in this case, tended to thematic analysis the Roma song lyrics, thereby it created the categorization of content themes and found the frequency of the occurrence of topics. However, we were also interested in the relationship between categories, so we looked at the songs from a qualitative view, in order to understand how the lyrics actors / figures experience different events, what importance they attach to it and how it is reflected in the process of consolidating Roma identity. This approach seemed necessary to obtain more integrated picture of reality and the subsequent comprehensive interpretation of the results of the thematic content analysis. The purpose of combination of both approaches, was to create a paradigmatic model of the Roma song, including the results of frequency analysis and findings identified by the qualitative approach.

\section{Research sample}

The available research sample for the content analysis of Roma lyrics became the whole three collections of Slovak ethnomusicologist Jana Belišová with 497 songs, containing the set of 211 new Roma songs and 286 old-time Roma songs.

1. Belišová, Jana, 2002. Phurikane gil’a. Starodávne rómske piesne.

2. Belišová, Jana, 2006. Hoj ne nej na. Phurikane gila 2.Tanečné rómské piesne.

3. Belišová, Jana, 2010. Neve gil’a. Nové rómske piesne.

\section{Research questions}

In our investigation, we observed, if the songs reflect the life experience and living conditions of the Roma, the family phenomena, crises and difficult life situations, emotions, socially negative aspects, the Roma community and living conditions of the Roma.

The main research questions were defined as follows: 
- What topics appear in the Roma song lyrics?

- What is the frequency of individual categories of the Roma songs themes?

- How do the songs reflect the family phenomena, crises and difficult life situations, emotions, socially negative aspects, the Roma community and living conditions of the Roma?

\section{Research description}

Text analysis was implemented in several steps. Primarily, we predefined categories / topics, as recommended, therefore, the first step was a thorough study of one set of songs, during which we made notes about the topics (categories) occurring in lyrics. We noticed the characters appearing in the text, situations, environment, emotions, living conditions and well-being. At that moment, we identified the coding sampling unit - particular lyrics and the analytical recording units - phrase or word. Secondly, we grouped all these recorded data into categories based on the study of the text and notes.

For example, there have been found mentions about poverty, misery, lack of finances, inadequate housing in the coding sampling unit, so these were gathered into category called Living conditions, illness, death or breakup with a partner into category Oppressive or crisis situations, mentions of alcoholism, fights, violence, imprisonment and other crimes into Social negative effects etc. Finally, the coding categories were defined after this procedure as follows:

Table 1. Defined categories

\begin{tabular}{|r|l|}
\hline 1 & Description of beauty \\
\hline 2 & Expression of love \\
\hline 3 & Expression of sorrow \\
\hline 4 & The phenomena of music, singing and dancing \\
\hline 5 & Other life events \\
\hline 6 & Religious symbolism \\
\hline 7 & Family community \\
\hline 8 & Roma community \\
\hline 9 & Coexistence with the majority \\
\hline 10 & Social negative effects \\
\hline 11 & Oppressive or crisis situations \\
\hline 12 & Living conditions \\
\hline
\end{tabular}

Source: Own research. 


\section{Coding process}

For purposes of analysis Excel program was used. Each coding unit (lyrics) was analysed separately and individual analytical units were assigned to predefined coding categories.

In the process of analysis, the categories were further internally divided into subcategories better reflecting the content and the meaning of the unit. Thereafter, text data in individual categories / subcategories were transferred (when possible) into the numeric form. In practice it meant, e. g. that the mention of the mother was categorized into column Family as number 1 - mother (number 2 marked father, 3 - children, etc.). Concurrently, significant moments, frequent connections and context were listed in the relevant categories in the verbal form. In this way, a coding book depicting the frequency of individual themes was created, as well as their most subcategories with basic descriptions of the essential facts. Finally, the data were added in each category and subcategory, organized into frequency tables and expressed in graphs.

For illustration, we present coding directly in the text of the selected songs:

Sample no. 1:

Roma song - Amare khera bare tičkendar (Belišová, 2002, p. 16)

Romani language:

Amare khera bare tičkendar, (3)

de dičhol andre baro čoripen. (4)

Joj, nane love, bo som čoro, $(2,4)$

jaj, Devlale, bo som čoro, $(1,4)$

de korunaha na birinav. (2)

(English translation)

Our houses are of big slats, (3)

poverty is visible inside. (4)

Oh, there is no money, becouse I am poor. $(2,4)$

Joj, God, because I am poor, $(1,4)$,

Crowns are not sufficient to me. (2)

Sample no. 2:

Roma song - Avlas ke man mro phral (Belišová, 2010, p. 115)

Romani language:

Avlas ke man mro phral te phenel, (5)

av tu sidžar khere e daj merel. $(5,6)$ 
Me o lestar džanav e daj merel, (5,6)

le Devlores mangen te nadžal. (1)

(English translation)

My brother came to me and said, (5)

Come home quickly, my mom is dying. $(5,6)$

I know about it, my mom is dying, $(5,6)$

We ask God to she did not die. (1)

(1) Category: Religious symbolism: Addressing God

(2) Category: Living conditions: Subcategory: Lack of money

(3) Category: Living conditions: Subcategory: Substandard housing

(4) Category: Oppressive or crisis situations: Subcategory: Poverty

(5) Category: Oppressive or crisis situations: Subcategory: Death in the family

(6) Category: Family community: Members of the family: brother, mother

\section{Findings}

First, the frequency of themes of the Roma songs was analysed. After assigning frequencies to each predetermined categories, we received frequency values, which were ranked in order of the frequency.

Table 1 shows the categorization of song topics. We found that themes of the Roma songs are very repetitive. Definitely, the most frequent is the theme of the family. A lot of the songs have the form of an interview between a mother and her son or her daughter, between lovers etc. The salutation of the person with whom the singer talks, communicates - even addressing God, it often appears. The singer often turns to his people, therefore the salutation "Romale" / Roma is typical. Very sad and depressive themes reflecting the hard life of the Roma as a marginalized group, poverty and suffering, disease and death are dominant.

Table 2. Categorization of topics

\begin{tabular}{|l|c|}
\hline \multicolumn{1}{|c|}{ Categorization of topics } & Mentions in \% \\
\hline Family community & 29 \\
\hline Oppressive or crisis situations & 16 \\
\hline Expression of love & 13 \\
\hline Social negative effects & 9 \\
\hline Roma community & 7 \\
\hline Expression of sorrow & 7 \\
\hline The phenomena of music, singing and dancing & 5 \\
\hline Living conditions & 5 \\
\hline
\end{tabular}




\begin{tabular}{|l|c|}
\hline Religious symbolism & 4 \\
\hline Description of beauty & 2 \\
\hline Other life events & 2 \\
\hline Coexistence with the majority & 1 \\
\hline TOTAL FREQUENCY OF MENTIONS & 100 \\
\hline
\end{tabular}

Source: Own research.

We also found a few other themes than those we previously defined into categories, mentions of the concentration camp or "mockery" themes (mainly in the dance songs). However, mentions of education, schools, teachers, students were completely absent. Mentions of the nature are reduced to poetic metaphor of some events; for example, a black bird shows the death. Description of the nature is shown only as a background where the main topic takes place.

Figure 1. Mentions of individual family members

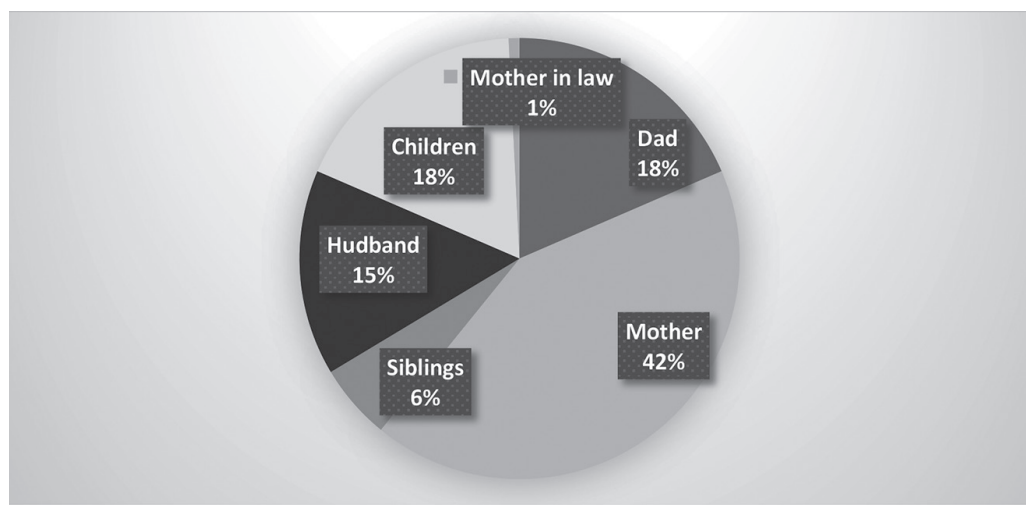

Source: Own research.

As far as all mentions of individual family members are concerned, the reference to the mother ranks unequivocally first with $42 \%$ of all references to family members. The mother is mentioned in connection with death, illness and abandoning children and also in a simple expression of a participant / singer of a song through questions Mum, what shall I do? / Mum, what have you done to me? or simple expression Oh, mummy. She is often presented as the one giving pieces of advice about life to her sons and daughters, the one helping with choosing a life partner for her kids, the one who the rest of the family is mourning for when she is ill or dying. The mother mentioned in 
songs is called out for help, invited to give advice and regarded as an indispensable person who cannot be lived without.

The father has occupied $18 \%$ of all mentions of family members in songs. As opposed to references to the mother, he is neither connected with giving advice or punishment in case of non-observance of given pieces of advice nor there are any feelings of sorrow and mourning his loss - death. In many songs, only the expression $d a d d y$ is used that is oftentimes mentioned together with addressing the mother. (Note: Romani language does not know the term parents, therefore, it uses the phrase father and mother). The same percentage (18\%) is found in the occurrence of children. References to husband / wife are also discovered. In the majority of cases they are only mentioned in various situations that are described in songs (e.g. separation, illness, death etc.).

If the frequency data of the category related to a family and the theme of love expression that is closely related to the choice of a life partner (potential family member) are combined, the results are even more unambiguous. The theme of a family or topics related to starting a family are present in almost $80 \%$ of all songs. In 395 cases out of total 497 songs there are mentions of family members or potential family members.

The revealed data directly corresponds to statements about the importance of a family and a close family relationship for the Roma ethnic group as the highest value. Family is irreplaceable for them and this fact is also originally reflected in songs. Family has always satisfied basic necessities of life of all its members, it has been its livelihood, it has fulfilled the educational function because sons have learned some traditional crafts in the family and daughters have learned how to take a good care of their children and husbands. In addition to that, we also notice the protective function of the family. Therefore, the Roma people deeply identify themselves with their families. As far back as when they led the nomadic way of life they were entirely independent of the outside society, however, inside their family they were totally dependent on each other in all areas. This aspect of the Roma functioning inside a family can be read from song texts. The most frequent and, it is possible to say, the most significant family member represented in songs is the mother. Even though on the outside, women generally have a lower status than men, inside Roma families it is the mother who occupies an entirely privileged position. It corresponds with what we see in the Roma songs which is the strength of a woman who is taking care of her family, who has a deep relationship with her children and who is entitled to interfere in selection of life partners of her children. In songs, disobeying the mother is 
compared to disobeying God, therefore, a punishment in the form of poverty or other misfortune comes as a consequence of such disobedience.

Figure 2. Mentions of oppressive or crisis situations

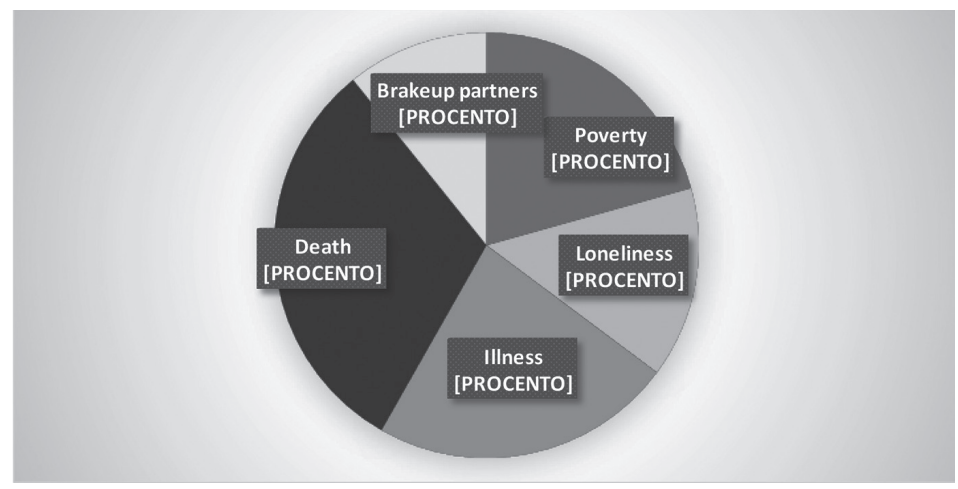

Source: Own research.

As results from Figure 2, discovered difficulties and crisis situations in the Roma songs are most frequently bereavement, one's illness or illness in the family, poverty and misery, loneliness and seclusion as well as separation. These situations influence the participants deeply and represent a heavy shock for their characters with far-reaching implications for their personal lives. In these situations, they consequently evaluate their lives, try to rediscover the meaning of life and turn to God. It seems that these situations thus support back the close relationships in families and strengthen ethnicity of the Roma.

Figure 3. Mentions of social negative effects

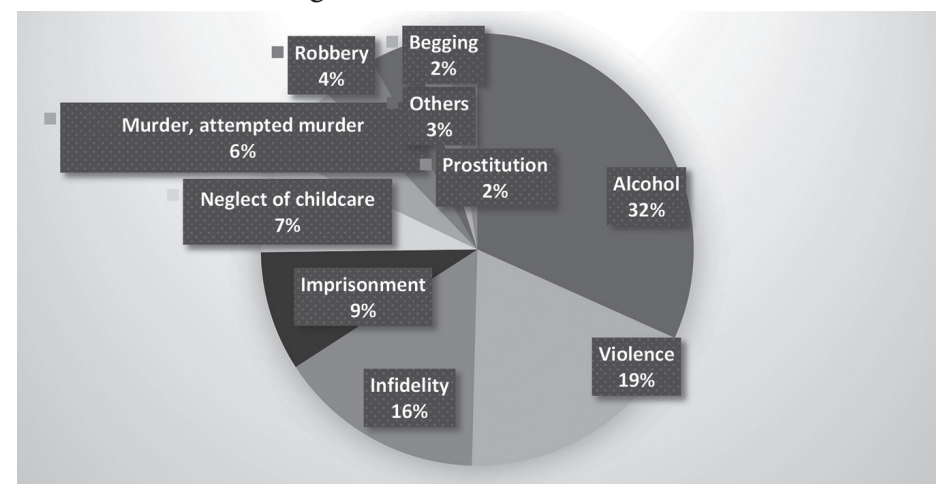

Source: Own research. 
The exact enumeration of individual detected kinds of undesirable actions can be seen in Figure 3. In songs, a wide range of socially undesirable phenomena has been revealed: excessive alcohol consumption and alcoholism, violence and aggression, infidelity and promiscuity, imprisonment, child neglect, murders, thefts, beggary, prostitution, usury and gambling. Some of these phenomena could be characterized as criminal or illegal acts. In total, references to such behaviour and acts have been discovered in $23 \%$ of songs. It makes this theme highly significant as far as the frequency is concerned.

Figure 4. Comparison of the topics of old and new Roma songs

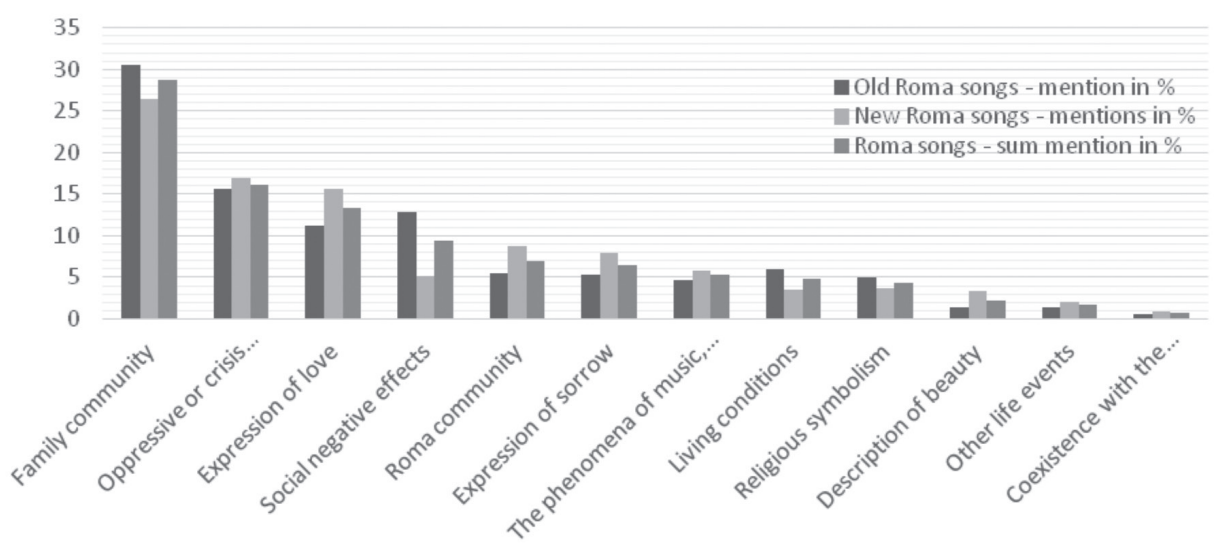

Source: Own research.

Differences in the order of topics and in the frequency of occurrence of individual categories of old-time and new songs can be seen in Figure 4. The first column represents the frequency of mentions in percentage in old-time songs, the second column represents the frequency in new songs and the third column shows the total frequency of occurrence of references expressed in percentage out of all recorded ones.

Furthermore, based on the obtained data we regrouped and merged the original categories, to better interpret the results. We merged category Oppressive or crisis situations, Social negative effects and Living conditions and we received a new category, which we collectively named Social problems. Furthermore, by combining categories Expression of love and Expression of sadness, a new category - Expression of emotions was created. The categories Description of beauty, Other life events and Coexistence with the majority that did not achieve such significant frequency, we merged into 
the category of Other topics. According to this review, we acquired six most important and most frequent topics of the Roma songs, listed in Table 2. Now, we can clearly see that the priority theme of the Roma songs are social problems. This confirms our initial premise that Roma lyrics reflect the life of this ethnic group, facts and situations that people experience. Closely behind, we find the theme of family and the trio of most frequent topics concludes category Expression of emotions.

Figure 5. Re-categorization of topics

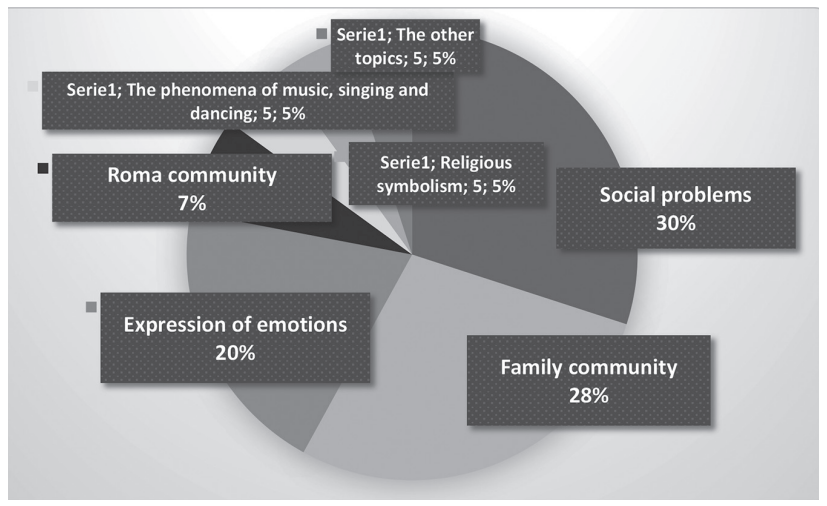

Source: Own research.

Figure 5 clearly indicates that the priority theme of the Roma songs is represented by social matters. It confirms the original assumption that Roma songs reflect lives of the Roma people themselves and the facts and situations they experience. This theme is closely followed by the theme of a family as the highest and the most important value and the imaginary trio of themes that significantly (as far as the frequency is concerned) exceed other themes is completed by the category of Expression of emotions.

Social problems closely remark lives of central actors / singers and objects of the Roma songs, especially all family members. Moreover, this experience reflects in their view and participates in the consolidation of Roma identity in two directions. In a positive way, it supports the component of Roma identity - cultural traditions, socio-cultural patterns, sense of belonging, consciousness and historical roots. On the other hand, we can see how seriously it threatens and depreciates members of the Roma minority and reflects in the folder of the identity in a negative way. So constant experiencing of social problems helps build the identity of the aggrieved, identity of isolation, 
identity of confrontation, which of course leads to bitterness, defiance and hostility. Social problems are the cause of emotions of sorrows expressed in songs, such as grief, pain or hopelessness. Emotions are responses to all these vitally important situations.

Figures acting in the songs are mainly from the immediate family circle, where the mother holds an exclusive place. The actor / singer strongly identifies with the family. This fact corresponds with aspects of Roma identity "Romipen" and it confirms the position of the family as the most important social group and institution. The family and home are typical backgrounds of the Roma songs. The aspect of the family community is with a significant position of the topic Expression of love even more enhanced. According the librettos, a partner selection is carried out within the family and the most respected mentor in this area is children's mother. The faith is a further feature of Roma identity, which is irreplaceable in the form of songs, persons confess to God, accept their punishment, they pray for their lives, for purification and healing of their loved ones.

\section{Discussion}

The main purpose of this research was to look at the authentic Romani texts from the perspective of social pedagogy and to highlight living conditions, social problems, events and the experience faced by the Roma minority. By the procedure of the thematic content analysis, the original assumption that the songs mirror the hard life of the Roma was confirmed. We recognized that the basic platform of Roma songs are social problems - unsatisfactory living conditions, difficult and crisis situations, crime and other socially undesirable phenomena, reflecting the hard life of the Roma ethnic group full of deprivation and hardship, mirroring the situation which Roma people essentially experienced in the past and which are still real for them. Lyrics of current Roma songs are the live music formation, flexibly respond to social situations and are a reflection of the inner life of their authors and their relationship to the outside world. The most common themes that she found in today's Romani texts are very similar: love to the family, to life, to God, to the life cycle (the upbringing of children, illness and death), difficult fate of the Roma (misery, poverty, rejection and racism), cohesion of the group, moral values. Similarly to our results, mentions of the agricultural year, labour and crafts, school, metaphors and descriptions of the countryside and the nature, typical for the Czech and Moravian folklore, are completely absent (or are very rare). 
Overall, the results of this study agree with the view of Ševčíková (2008, p. 88) seeing the Roma songs as the most typical and the best means of expressing oneself in intimate confession filled with pain and grief, in which we can see the shadow of the traumas that Roma people as a nation have passed. Nevertheless, they maintain a proud demonstration of their own identity. The song repertoire mirrors a desire for self-purification, love confession and heartfelt supplications to God, reflects typical Roma patterns of behaviour aroused from traditional nomad's way of life.

The general aim of this study was not to provide solutions to social problems that this minority faces, but to highlight the phenomenon of the Roma music as a material with an enormous revealing value. Our intention and crucial desire was to bring this unique treasure of Roma culture to the discourse of social pedagogy as a discipline combining other sciences in a specific way from whose perspective Roma music can be examined. We are aware that despite the great authenticity of the testimony of lyrics, it does not consider totally the map of experiences and the inner world of this minority. Moreover, although the method of content analysis provides mostly relevant data, they are not very specific and accurate as an interview on a particular subject. On the other hand, the great advantage of examining the original texts - fairy tales, stories or lyrics - lies in the fact that the statements are unintentional and spontaneous.

However, we believe that our results can provide the significant insight into this issue. Generally, we find the area of the original Romani texts as a very good field for further research, e.g. examining the values, main aspects of the culture or typical patterns of behaviour. Consequently, the results of such studies can enrich the socio-pedagogical practice and can be used in pedagogy or social work with children and adults from the Roma, minority in the sense of a deeper understanding of this specific ethnic group.

\section{Acknowledgment}

This article was based on the grant project IGA SV60171706020 / 2110 The concept of educational values from the perspective of pupils from different cultural backgrounds. However, any mistakes that remain are my own. 


\section{Bibliography}

Belišová, J. 2002. Phurikane gila. Starodávne rómske piesne. Bratislava: Žudro.

Belišová, J. 2006. Hoj na nej na. Phurikane gil’a 2. Tanečné rómské piesne. Bratislava: Žudro.

Belišová, J. 2010. Neve gil’a. Nové rómske piesne. Bratislava: Žudro.

Davidová, E. 1999. Čhajori romaňi. Romská dívenko: Výbor z romské písňové poezie. Praha: Ars Bohemica.

Davidová, E. and Jurková, Z. ed. 2001. Vlachicka djila: nejstarší terénní nahrávky hudebního folkloru olašských Romi̊ z České a Slovenské republiky. Praha: Academia.

Hübschmannová, M. 2002. Šaj pes dovakeras. Můžeme se domluvit. Olomouc: Univerzita Palackého v Olomouci.

Malvinni, D. 2004. Gypsy caravan: from real Roma to imaginary Gypsies in western music and film. New York: Routledge.

Piotrowska, A., G. 2013. Gypsy music in European culture. From the late eighteenth to the early twentieth centuries. Boston: Northeastern University Press.

Rădulescu, S. 2004. Taifasuri despre muzica tiganeasca: chats about Gypsy music. Bukuresti: Paideia.

Sárosi, B. 1978. Gypsy music. Budapest: Corvina Press.

Scheinostová, A. 2011. Ženská romská próza jako zápas o sebevyjádření. In Matonoha. J. ed. Česká literatura v perspektivách genderu. IV. kongres světové literárněvědné bohemistiky: Jiná česká literatura. Praha: Ústav pro českou literaturu AV ČR, pp. 253-263.

Silverman, C. 2012. Romani Routes: Cultural Politics and Balkan Music in Diaspora. New York: Oxford University Press.

Slovo 21, (92018. Projekty. Slovo 21.cz [online]. Available from: http://www. slovo21.cz/index.php/extensions (5.05.2018).

Ševčíková, S. 2011. Sebepojetí Romů v romské lidové slovesnosti. Disertační práce. Brno: Masarykova univerzita v Brně. Fakulta sociálních studií.

Ševčíková, V. 2003. Sociokulturni a hudebně výchovná specifika romské minority v kontextu doby. Ostrava: Ostravská univerzita.

Ševčíková, V. 2008. Slyšet, cítit, dotýkat se...: Romská hudba a hudebnost Romů jako pozitivní kulturní stereotyp a dominantní kulturní konfigurace. Šenov u Ostravy: Ostravská univerzita v Ostravě. 


\section{Roma song lyrics: a mirror of social phenomena and values of the Roma ethnic group}

Abstract: The paper deals with Roma music, a unique treasure of Roma culture.
The music which lies in the centre of several disciplines closely related to social
pedagogy is the only positive cultural stereotype and possible link between the
Roma minority and the majority society. This study focuses on the lyrics of Roma
songs as a means of self-expression of this ethnic group, as a mirror reflecting the
life experience and living conditions, as one of the cultural attributes with which
the Roma has been strengthened. Roma songs as a source of the highly authentic
testimony of the Roma themselves are a subject to the content analysis, with the
aim to find the most significant social-pedagogical problems.

Keywords: Roma songs, ethnic minority, gypsy music, cultural identity, content analysis

Transleted by Iva Staňková 